\title{
Barriers to physical activities of college students with disabilities
}

\author{
Ibrahim Mohammad Harafsheh ${ }^{a^{*}}$, Faleh Aultan Abu-eid ${ }^{a}$, Salwa Adnan Alshorman ${ }^{a}$ and Enshirah Abdul- \\ lah Kanaan ${ }^{a}$
}

${ }^{a}$ The Hashemite University, Jordan

\begin{tabular}{l}
\hline C H R O N I C L E \\
\hline Article history: \\
Received: April 29, 2020 \\
Received in revised format: \\
April 30 2020 \\
Accepted: May 30, 2020 \\
Available online: \\
June 2, 2020 \\
\hline Keywords: \\
Facilities \\
Social \\
Academic \\
Psychology \\
\hline
\end{tabular}

\section{A B S T R A C T}

\begin{abstract}
This study was to demonstrate the reasons why people with special needs could not practice activities. The researchers used some descriptive methods which was suitable for the aim of the study. The sample of the study was 42 students with special needs at Hashemite university. The researchers used a scale consist of 5 dimensions; physical, facilities, social, academic and psychology. The result shows that the academic reason was the main barrier that forbidden students with special needs to practice physical activities followed by the social reasons, facilities and psychological reasons. The researchers recommend to hold lectures and seminars in order to spread the benefits of physical activity, to build gyms that are suitable for students with special needs, and to employ staff who can deal with different needs.
\end{abstract}

(C) 2020 by the authors; licensee Growing Science, Canada

\section{Introduction}

Human beings in this age are characterized by inactivity, laziness, and lack of movement as a result of the great scientific and technological progress, as well as the knowledge revolution that covered different areas of life (Aljawarneh \& Atan, 2018; Aljawarneh \& Al-Omari, 2018; Khuong et al. 2020). Individuals generally depend on the machine rather than movement, which made the problem of the spread of modern diseases very prevalent, especially in what is known as the diseases of lack of movements such as obesity, high blood pressure, osteoporosis, psychological diseases, and others (Al-Omari, et al., 2020). The exercise of physical activity is considered a necessity related to the preventive health of every member of society and in various stages of life because it is one of the best ways to maintain and improve the general health of the individual. The results of the studies indicated the positive impact of physical activities on the various body parts, including the circulatory system, muscle, nervous and social and psychological aspects of the individual (Goodman \& Whitaker, 2002; am et al., 2019), through the practice of sports activities, the fitness of the individual improves and the elements of physical fitness evolve like speed, strength, flexibility, agility and so on. The practice of sports activity of all kinds is a human activity that is rich in many competitive positions and may have a great effect on the personality of the individual. Activity plays a special role in raising personal human experience and excellence and contributes to improving quality and developing social spirit and communication with others, which is reflected in increasing the productivity of the individual (Al-Jawarneh, 2016). Sports activities are generally more important for people with disabilities, as the importance of sports activity for people with disabilities is doubled due to their lack of mobility due to their disability and concomitant conditions. Therefore, developed societies have attached great importance to the exercise of sports in their belief in the importance of sports in reducing the chances of previous diseases and the positive effects on the lives of the individuals, whether in the health, psychological or social sphere, whether of poor individuals or with special needs/ Attention has begun to be paid clearly to those with special needs in order to create a better life and a level appropriate to them. This is exemplified by the 1981 UN International Year of Disabled Persons. Many laws have been enacted that have contributed to the integration of people with special needs into society. This category of society

* Corresponding author.

E-mail address: ibrahimharafsh@gmail.com (I. M. Harafsheh) 
has changed in view of those who suffered persecution, torture, and humiliation at the time of Plato, Aristotle and the Roman times, where they were starving to death when they were children (Yahya, 2005; Hassan \& Din, 2019).

In the middle Ages, disability was defined as the anger of God and also as the expression of wicked spirits (Alwagfi et al., 2020). The view of the disabled was fear because they believe that the gods have cursed them, as they are not worthy of mixing between people and should be kept away from them and not contact with them (Al-Da'abseh, et al., 2018). The way societies treat people throughout the different ages with the disabled people between injustice, kindness, displacement, and humanity, in the modern age, as a result of progress and prosperity in all aspects of scientific, psychological and social life. Society's view of people with disabilities has increased, especially after the Second World War, and the number of people with disabilities as a result of the effects of war and other causes of disability has increased (Mahafzah et al., 2020). People with disabilities are now seen as working and producing in society if their remaining abilities are exploited and properly directed to be active in society and be an active element in society (Alshare et al., 2020).

The view of people with disabilities has been completed after many laws and regulations have been drafted that give everyone the right and require various institutions to provide all means and facilities to people with disabilities to integrate and interact in life, whether in schools or universities or to obtain suitable jobs, equal to all members of society, which culminated in the United Nations International Convention on the Rights of Persons with Disabilities in 2007 and the signature of most countries, including Jordan, and they have established their own centers and created different ways to deal with them, and programs have been developed that suit their capabilities and needs. Sports activities and programs have been one of the first events to be offered to people with special needs, whether on the therapeutic, recreational or competitive side, and all kinds of sports activities have been introduced to suit their abilities, and tools, devices, security and safety factors have been provided to ensure good practice and increased awareness and sports thought among them.

Through the work of physical education researchers in a government university, they noted the reluctance of disabled students to practice sports, in spite of the availability of tools and capabilities that suit their needs, as well as calls more than once through different means of communication with students to practice sports and to demonstrate the importance of sports in life in general. The idea of this study is to find out the real reasons why disabled students are reluctant to practice sports at the university and to try to overcome obstacles in cooperation with the competent authorities in order to involve disabled students in university sports activities, just like their colleagues. The study aims to identify the reasons for the reluctance of disabled students to exercise sports at the Hashemite University and to identify the differences in views on the reasons why disabled students are reluctant to exercise sports according to the changes in the study.

\section{Literature Review}

Irish Sports Council, (1999) posits that it is important for a person with a disability to get involved in physical activity, as they generally lead a more sedentary life compared to the general public. In the European Charter for Sport for All: Disabled People are suggested to practice and "sport for all" should include individuals with disabilities for different reasons: (1) they have the same rights to sport as non-disabled people do, (2) sport adds to the quality of life, (3) athletes with disabilities can compete on the elite level, and (4) people with disabilities receive both physiological and social benefits from participation (Council of Europe, 1986). According to Davis et al. (2000) participation in sport is not only essential, but also it is important that people with disabilities are encouraged to remain physically active. Health Education Authority, (1997) Posits that it has been found that an active person in early life have better life. According to "the commission on the status of people with disabilities" in the year 1996, 20,800 individuals were indicated as disables with a disability and participating in organized sporting clubs/events. Thus, this figure represents $6 \%$ of the total population of people with a disability, while $53 \%$ of them were able bodied population who participated in physical activities and in the summer months this figure reached to $60 \%$ participation (Department of Health and Children 1996). Participation in exercise also plays in rehabilitation and supporting social contacts, and this can provide people with disabilities with an outlet to enjoy themselves. According to the Irish Sports Council (1999) a key challenge identified by the Irish Sports Council is the need to promote social inclusion and equity and widening the accessibility of sport to all.

The most prominent barriers faced by people with disabilities were the attitudes of others, inaccessibility, transport, communication and finance, in general environment (Al-Omari et al., 2018). Additional barriers included the lack of coaches/trainers and family. In other words, for participation in exercise and physical activities, the attitudes of service providers were also identified as constrain, in that it was viewed that they were often ignorant of the requirements of people with physical and sensory disabilities (The Department of Education, 1997).

\section{The methodology}

The researchers used some descriptive methods to suit the nature of the study. The study population consists of all 42 students with disabilities at the Hashemite University distributed according to Table 1 as follows, 
Table 1

Distribution of sample study by study variables

\begin{tabular}{|c|c|c|c|c|c|c|}
\hline Number & Variable & Total & Percent & Gender & Number & Percent \\
\hline \multirow[t]{2}{*}{1} & Gender & 42 & $100 \%$ & Male & 20 & $48 \%$ \\
\hline & & & & Female & 22 & $52 \%$ \\
\hline \multirow[t]{2}{*}{2} & Impaired mobility & 15 & $35.7 \%$ & Male & 8 & $53 \%$ \\
\hline & & & & Female & 7 & $47 \%$ \\
\hline \multirow[t]{2}{*}{3} & Visual impairment & 14 & $33.3 \%$ & Male & 5 & $36 \%$ \\
\hline & & & & Female & 9 & $64 \%$ \\
\hline \multirow[t]{2}{*}{4} & Impaired hearing & 13 & $31 \%$ & Male & 7 & $65 \%$ \\
\hline & & & & Female & 6 & $46 \%$ \\
\hline
\end{tabular}

Based on the studies accomplished by Hammouda and Al-Rifa'e (2008), Al-Hayek and Musaad (2008), and Khoja and Omar (2008), which dealt with the reasons for the sample reluctance to practice sports activity, this survey was designed as a data collection tool to match the sample of study. The survey consisted of 40 paragraphs distributed in five areas of psychological, physical, health, social, academic and possibilities. The survey was presented to a group of arbitrators to determine the suitability of the paragraphs to the sample study, so that the arbitrators expressed their views on the survey and some paragraphs were deleted, added or modified to the determination in accordance with the opinions of the arbitrators, the final survey reached to 34 paragraphs. To ensure the consistency of the survey, the testing and re-testing method were used on a sample of 6 students and Table 2 shows the results between first and the second applications.

Table 2

Correlation between the first and second applications

\begin{tabular}{|c|c|c|c|c|c|c|}
\hline \multirow[t]{2}{*}{ Fields } & \multicolumn{2}{|c|}{ First Application } & \multicolumn{2}{|c|}{ Second Application } & \multirow[t]{2}{*}{ Correlation } & \multirow[t]{2}{*}{ Semantic level } \\
\hline & Mean & SD & Mean & $\mathrm{SD}$ & & \\
\hline Psychological field & 2.6 & 0.5 & 2.4 & 0.64 & 0.91 & 0.00 \\
\hline Academic field & 2.8 & 0.4 & 2.7 & 0.71 & 0.88 & 0.00 \\
\hline Social field & 3.22 & 0.33 & 3.3 & 0.12 & 0.90 & 0.00 \\
\hline Health and physical & 2.6 & 0.64 & 2.5 & 0.24 & 0.89 & 0.00 \\
\hline Field of Material Capabilities & 3.5 & 0.7 & 3.1 & 0.61 & 0.89 & 0.00 \\
\hline All & 2.94 & 0.51 & 2.8 & 0.46 & 0.894 & 0.00 \\
\hline
\end{tabular}

We note that the correlation coefficient values for the study areas were between 0.88 and 0.91 and that the total correlation coefficient value for all areas was 0.894 and this value is high, which indicates a strong correlation between the first and the second application of the tool.

\section{The results}

In light of the study's objectives and questions, the findings of the researchers will be presented as follows: The first question is, what are the reasons for the reluctance of disabled students to practice sports at Hashemite University? In order to answer this question, the researchers used the arithmetic mean and standard deviation of each paragraph of the resolution and the results are summarized in Table 3 to Table 7.

Table 3

mean and SD Relative importance of the first area of the instrument, which is the psychological field

\begin{tabular}{|c|c|c|c|c|c|}
\hline Number & Paragraph & mean & SD & Percent & Order in Survey \\
\hline 1 & Practicing sports doesn't improve my concept of myself. & 1.7 & 0.63 & 0.42 & 6 \\
\hline 2 & Sports don't improve my ability to deal with problems. & 2.0 & 0.68 & 0.50 & 4 \\
\hline 3 & Playing sports doesn't reduce inhibition and depression. & 1.9 & 0.67 & 0.47 & 5 \\
\hline 4 & Practicing sports doesn't help me overcome my disability. & 3.2 & 0.6 & 0.80 & 3 \\
\hline 5 & Parents do not encourage me to practice sports in the university & 3.6 & 0.47 & 0.90 & 1 \\
\hline 6 & My lack of exercise is due to the unsatisfactory deal of univer- & 1.6 & 0.57 & 0.40 & 7 \\
\hline 7 & I feel like sports supervisors aren't able to deal with people with & 1.6 & 0.48 & 0.40 & 7 \\
\hline 8 & There's nothing that motivates me to practice sports & 3.5 & 0.5 & 0.87 & 2 \\
\hline 9 & I don't feel good and enjoy when I am doing sports & 1.4 & 0.5 & 0.35 & 8 \\
\hline
\end{tabular}

According to Table 3, we note that the paragraph of not encouraging parents to practice sports in the university was the first reason with an arithmetic mean and a standard deviation 3.6 \pm 0.74 , while lack of motivation was the second reason with an arithmetic mean and a standard deviation of $3.5 \pm 0.5$. While "the sports activity paragraph didn't help me overcome my disability" comes in the third place with arithmetic mean and standard deviation $3.2 \pm 0.6$. Researchers see that this result is logical, as encouraging parents is one of the most important things that support children and their orientation for sports participation, whether on the recreational or competitive side We live in an Eastern society where children are somewhat committed to their parents' guidance and respect their opinions, whether the thoughts of fathers are open and encourage participation in various sports programs for males or females, or their thoughts are strict which means it is against traditions. By reviewing the responses of the sample members in the previous table, we have noted that the view of the practice of sports by parents is still modest, especially if their children with special needs are small, although disabled individuals are among the 
neediest groups in society to practice sports activities where the exercise of sports is considered preventive and therapeutic activities that contribute to mitigating their effects. Also disabled people need support and encouragement from their parents to participate in sports activities so that participation can help them come out to life and integrate into the sports community first and then into the university community and come out to public life later. This result agreed with the study of Al-Hayek and Masaad (2008) in terms of the importance of psychological support and encouragement for children to practice sports.

Table 4

Arithmetic mean, standard deviation and relative importance of the second field of the instrument, the academic field

\begin{tabular}{|c|c|c|c|c|c|}
\hline Number & Paragraph & mean & SD & Percent & Order in Survey \\
\hline 10 & I don't find the time to practice sports at university & 3.4 & 0.5 & 0.85 & 2 \\
\hline 11 & The person who plays sports is not more productive in his work & 1.4 & 0.5 & 0.35 & 6 \\
\hline 12 & Practicing sports doesn't help me to use my free time at university & 1.7 & 0.6 & 0.42 & 5 \\
\hline 13 & Doing sports activity affect negatively on my Academic Achievement & 3.2 & 0.61 & 0.80 & 3 \\
\hline 14 & My future study is more important than my practice of sports & 3.6 & 0.46 & 0.90 & 1 \\
\hline 15 & The time for a sports activity is not Appropriate with my study time & 3.1 & 0.45 & 0.77 & 4 \\
\hline
\end{tabular}

According to Table 4, researchers see that there are some misconceptions adopted by some people that affect their lives. For instance, practicing sports is considered as a waste of time to be used in studying and achieving the best grades at school. Some university students believe that their academic futures are in conflict with their practice of sports. However, practicing sports is not in conflict with this goal, but it helps students organize their time and use free time. Practicing sports also makes students less susceptible to anxiety and tension and develop their abilities to depend on themselves and the power of concentration. Some studies, (e.g. Abu Tam, 2007; Khoja \& Omar, 2008; Dalila et al., 2020), indicated that students practicing sports are more productive than others and that the level of anxiety due to exams is lower than those who do not practice sports.

Table 5

Arithmetic mean, standard deviation and relative importance of the third area of the instrument, which is the social sphere

\begin{tabular}{|c|c|c|c|c|c|}
\hline Number & Paragraph & mean & SD & Percent & Order in Survey \\
\hline 16 & I'm ashamed of the others' view of me during doing my sports & 2.7 & 0.98 & 0.67 & 2 \\
\hline 17 & Playing sports doesn't increase my social relationships & 2.0 & 0.51 & 0.50 & 6 \\
\hline 18 & Society's view of people with special needs during exercise is unsatisfactory & 3.3 & 0.57 & 0.82 & 1 \\
\hline 19 & My colleagues don't want to be involved with me in sports because of my disability & 2.5 & 0.50 & 0.62 & 4 \\
\hline 20 & My fellow athletes don't cooperate with me while playing games & 2.4 & 0.50 & 0.60 & 5 \\
\hline 21 & a disagreement of parents or guardian to participate me in any sports activity & 2.5 & 0.91 & 0.62 & 4 \\
\hline 22 & I can't be creative in practicing the sport of special needs & 2.7 & 0.82 & 0.67 & 2 \\
\hline 23 & I don't know there are sports activities for people with special needs at university & 2.6 & 0.49 & 0.65 & 3 \\
\hline 24 & Lack of awareness of the importance of sports has affected my participation in sports ac- & 2.6 & 0.46 & 0.65 & 3 \\
\hline
\end{tabular}

Through the review of the Table 5, we note that the paragraph of "community view for people with special needs during sports activities is unsatisfactory", ranked first with arithmetic mean and standard deviation ( $3.3 \pm 0.57)$ while, "it was a shameful paragraph from the perspective of others in the exercise of sports", and "I cannot be creative in practicing the sports activity of people with special needs" come in second place with arithmetic mean and a standard deviation of (2.7 \pm 0.98$)$ and (2.7 \pm 0.82), respectively. The researchers see that the negative perception of the society of disabled individuals is still limited and unable to understand that disabled individuals have the rights and obligations to all citizens and disabled individuals have the right to exercise sports like all citizens, and that we should stand by them and support them in order to overcome their disabilities. This is what is stipulated in international laws and conventions, both in the International Year of Disabled Persons in 1981 and in subsequent laws issued by human rights organizations and international bodies that establish the basis for dealing with people with disabilities, whether in the educational, health, sports, employment or other aspects of the rights and duties of people with disabilities.

Table 6

Arithmetic mean, standard deviation and relative importance of the Tool's fourth area of health

\begin{tabular}{|c|c|c|c|c|c|}
\hline Number & Paragraph & mean & SD & Percent & Order in Survey \\
\hline 25 & I feel my disability makes me exempt from practicing sports & 3.3 & 0.57 & 0.82 & 3 \\
\hline 26 & My disability is disturbing me & 3.6 & 0.48 & 0.90 & 1 \\
\hline 27 & My disability prevents me from practicing sports & 3.5 & 0.50 & 0.87 & 2 \\
\hline 28 & My poor fitness reduces my exercise & 2.3 & 0.86 & 0.57 & 4 \\
\hline 29 & I feel doing sports is causing me health damage & 1.3 & 0.46 & 0.32 & 6 \\
\hline 30 & Increasing my obesity is preventing me from practicing sports & 2.1 & 0.88 & 0.52 & 5 \\
\hline
\end{tabular}

Through the review of Table 6 , we note that the disability paragraph cause me inconvenience was ranked first with an average of arithmetic and standard deviation $(3.6 \pm 0.48)$ while "my disability paragraph prevents me from practicing sports activity" came in the second place with an arithmetic average and standard deviation $(3.5 \pm 0.50)$. Researchers see that this is also a misconception repeated by some disabled people who believe that their disability prevents them from participating in sports, some students with disabilities at the university believe that because of the circumstances of the disability and the associated lack of feelings or organs, they are isolated from the society. It is believed that this lack is an obstacle to the exercise of sports activity or that it will be excluded from sports activities, which is the result of lack of awareness, education and lack of 
knowledge, as disabled individuals can now exercise all sports activities in proportion to their lack of physical senses or organs, after some modification have been made to the laws or special equipment of the type of sport so that it is suitable for their potential.

Table 7

Arithmetic mean, SD and relative importance of the Tool's Fifth Field, Field of Material Capabilities

\begin{tabular}{|c|c|c|c|c|c|}
\hline Number & Paragraph & Arithmetic mean & Standard & $\%$ & Order in Survey \\
\hline 31 & Health facilities are not equipped for special needs & 3.2 & 0.64 & 0.80 & 1 \\
\hline 32 & My inability to provide the sports clothes needed to practice sports & 2.5 & 0.51 & 0.62 & 3 \\
\hline 33 & The gym doesn't suit the needs of people with special needs & 2.4 & 0.50 & 0.60 & 4 \\
\hline 34 & Appropriate tools are not available for people with special needs & 2.9 & 0.62 & 0.72 & 2 \\
\hline
\end{tabular}

Through the review of Table 7, we note that the sanitation clause is not prepared for people with special needs, was ranked first with an arithmetic mean and a standard deviation ( $3.2 \pm 0.64)$, whereas "appropriate tools are not available for people with special needs" came in the second position with an arithmetic mean and a standard deviation $(2.9 \pm 0.62)$. The researchers believe that the design of sports facilities should take into account the special needs of the disabled individuals in terms of access, director, spare rooms and health facilities and the lack of good facilities may lead to withdrawal from participating in sports activities. In addition, the halls and equipment used in the activity, if not amended to match the capabilities of the disabled individuals in the university, will inevitably lead to a departure from sports activities and will not participate in any sports programs prepared by the University. The results are consistent with the study of many researchers such as Yehya (2005), Khoja and Omar (2008) and Abu Tam (2007). The result is that the unequipped health facilities and gym facilities do not match the needs of people with special needs and the lack of appropriate tools for people with special needs, which lead to reluctance to exercise sports by disabled people in the university.

Table 8

Arithmetic mean, SD and relative importance of Psychological field, academic and social domain, etc.

\begin{tabular}{llccc}
\hline Number & Field & mean & SD & Percent \% \\
\hline 1 & Psychological field & 2.4 & 0.33 & 0.60 \\
2 & academic domain & 3.5 & 0.48 & 0.87 \\
3 & Social domain & 2.9 & 0.47 & 0.72 \\
4 & Health and physical area & 1.3 & 0.72 & 0.32 \\
5 & Field of Material Capabilities & 2.6 & 0.72 & 0.65 \\
\hline
\end{tabular}

Through the review of Table 8 , we note that the academic field ranked first in terms of importance with arithmetic mean and a standard deviation $(3.5 \pm 0.48)$, whereas the social field was second in terms of arithmetic mean and standard deviation ( $2.9 \pm 0.47)$. Researchers see that disabled students in the Hashemite University were reluctant to practice sports for academic and social reasons because disabled students believe that practicing sports negatively affects their academic achievement and therefore use their free time with other activities that are not athletic and that they believe that it does not affect their academic achievement. This concept is wrong for students. Some studies have indicated that the practice of sports has a positive effect on academic achievement so that students can develop the determination, persistence, diligence, the spirit of challenge, the organization of time and other great benefits of practicing sports. Although the sample is different, the results of this study differ from those of Yehya (2005), Khoja and Omar (2008), and Abu Tam (2007). The previous studies pointed out that the reasons for the reluctance of the sample to practice sports activities are due to lack of Material Capabilities. The second question is: Are there any statistically significant differences in the reasons why disabled students are reluctant to exercise sports because of the gender variable? In order to answer this question, researchers used arithmetic averages, standard deviation and $(\mathrm{T})$ value for all areas of identification and the results were as follows

Table 9

Arithmetic mean, standard deviation and T value of study areas by gender variable

\begin{tabular}{|c|c|c|c|c|c|c|}
\hline Number & Field & Gender & mean & $\mathrm{SD}$ & Value of T & Semantic \\
\hline \multirow[t]{2}{*}{1} & \multirow[t]{2}{*}{ Psychological field } & Male & 2.4 & 0.33 & \multirow[t]{2}{*}{0.37} & \multirow[t]{2}{*}{0.71} \\
\hline & & Female & 2.4 & 0.36 & & \\
\hline \multirow[t]{2}{*}{2} & \multirow[t]{2}{*}{ Academic domain } & Male & 3.5 & 0.49 & \multirow[t]{2}{*}{0.63} & \multirow[t]{2}{*}{0.53} \\
\hline & & Female & 3.4 & 0.47 & & \\
\hline \multirow[t]{2}{*}{3} & \multirow[t]{2}{*}{ Social domain } & Male & 2.8 & 0.29 & \multirow[t]{2}{*}{1.5} & \multirow[t]{2}{*}{0.13} \\
\hline & & Female & 3.0 & 0.57 & & \\
\hline \multirow[t]{2}{*}{4} & \multirow[t]{2}{*}{ Health and physical area } & Male & 1.18 & 0.44 & \multirow[t]{2}{*}{2.8} & \multirow[t]{2}{*}{0.06} \\
\hline & & Female & 1.5 & 0.82 & & \\
\hline \multirow[t]{4}{*}{5} & \multirow[t]{2}{*}{ Field of Material Capabilities } & Male & 2.7 & 0.69 & \multirow[t]{2}{*}{1.5} & \multirow[t]{2}{*}{0.12} \\
\hline & & Female & 2.4 & 0.71 & & \\
\hline & \multirow[t]{2}{*}{ All } & Male & 2.5 & 0.33 & \multirow[t]{2}{*}{0.33} & \multirow[t]{2}{*}{2.4} \\
\hline & & Female & 2.54 & 0.66 & & \\
\hline
\end{tabular}

From Table 9, we note that there are no statistically significant differences between sample members related to the gender variable. The Semantic level ranged from 0.06 to 0.71 . All of these values are greater than 0.05 , which indicates that there are no differences between sample responses related to the gender variable. The researchers see that the psychological pressures 
on disabled students are dangerous during school years, as well as the social aspects and their effects on the disabled students, in addition to the health aspects and the lack of resources that match their abilities, disabled students suffer from it no matter they are male or female, we can see from the results that the T-test comparing the mathematical averages between males and females. The results showed that there were no psychological differences between male and female study variables. The third question is: are there any statistically significant differences in the reasons why disabled students are reluctant to exercise sports because of the variable of the type of disability? In order to answer this question, the researchers used arithmetic averages, standard deviation and single variation analysis for all areas of identification and the results were as follows,

Table 10

The results of the single analysis of study areas by type of disability

\begin{tabular}{|c|c|c|c|c|c|c|c|}
\hline Number & Field & Source & Sum of Squares & Degrees Freedom & Average Squares & $\mathrm{F}$ & Semantic \\
\hline \multirow[t]{3}{*}{1} & \multirow[t]{3}{*}{ Psychological field } & Between group & 0.61 & 2 & 0.30 & \multirow{3}{*}{0.73} & \multirow{3}{*}{0.48} \\
\hline & & Within groups & 16.4 & 39 & 0.42 & & \\
\hline & & Total & 17.7 & 41 & & & \\
\hline \multirow[t]{3}{*}{2} & \multirow[t]{3}{*}{ academic domain } & Between groups & 0.85 & 2 & 0.42 & \multirow{3}{*}{1.72} & \multirow{3}{*}{0.19} \\
\hline & & Within groups & 9.62 & 39 & 0.24 & & \\
\hline & & Total & 10.47 & 41 & & & \\
\hline \multirow[t]{3}{*}{3} & \multirow[t]{3}{*}{ Social domain } & Between groups & 0.22 & 2 & 0.11 & \multirow{3}{*}{0.43} & \multirow{3}{*}{0.65} \\
\hline & & Within groups & 10.17 & 39 & 0.26 & & \\
\hline & & Total & 10.4 & 41 & & & \\
\hline \multirow[t]{3}{*}{4} & \multirow{3}{*}{$\begin{array}{l}\text { Health and physical } \\
\text { area }\end{array}$} & Between groups & 2.83 & 2 & 1.41 & \multirow{3}{*}{4.22} & \multirow{3}{*}{0.21} \\
\hline & & Within groups & 13.07 & 39 & 0.33 & & \\
\hline & & Total & 15.9 & 41 & & & \\
\hline \multirow[t]{3}{*}{5} & \multirow{3}{*}{$\begin{array}{l}\text { Field of Material Capa- } \\
\text { bilities }\end{array}$} & Between groups & 4.91 & 2 & 2.45 & \multirow{3}{*}{5.85} & \multirow{3}{*}{0.06} \\
\hline & & Within groups & 16.37 & 39 & 0.42 & & \\
\hline & & Total & 21.2 & 41 & & & \\
\hline
\end{tabular}

From Table 10, we note that the value (P) ranged from 0.43 to 5.85. All these values are not statistically relevant at the $\alpha 0.05$ level, indicating that the responses of sample study members were not affected by the variable of the disability type, whether they were motor or sensory impairment (audio or visual).

\section{Conclusions}

In light of the study's objectives and questions, researchers conclude that: Academic reasons ranked first in terms of reasons why disabled students were reluctant to participate in sports activities, while health and physical areas were ranked last in importance. Parents have a prominent role in influencing the views of their children with disabilities and encouraging them or not to join the university community and practice activities. Disabled people are greatly affected by the general perception of society, which negatively affects their participation in sports activities. One of the misconceptions and beliefs of disabled students is that the practice of sports negatively affects their academic achievement. Some disabled students do not take advantage of their free time to exercise sports activities. Lack of awareness and education between some disabled students has led to the belief that disability prevents them from practicing sports and they do not know that there are special sports activities for the disabled in various sports in accordance with their abilities. Some university institutions did not take into their mind the needs of disabled students for health facilities, sports facilities, and equipment.

\section{Recommendations}

In the light of the study's objectives, and based on questions and discussion of the results, researchers recommend the need to spread sports awareness among disabled students, disabled students and members of society at large to combat the misconceptions about participation in sports activities through seminars, lectures or scientific research seminars directed at them, and to make use of the visual and audio media. To emphasize to scientific institutions, the university officials need to provide some requirements for disabled students in all buildings, facilities, and gymnasiums. 


\section{Acknowledgement}

The Authors would like to thank the anonymous referees for constructive comments on earlier version of this paper.

\section{References}

Abu Tam, B. (2007). Reluctance of Alkhadory college students in palatine for participants in sport activities inside colleges conference association colleges and institutes and sections physical education in the Arab world. Amman .Jordan

Al-Da'abseh, T., Aljawarneh, N., \& Shwiyat, Z. (2018). Marketing mix strategies and its impact on organizational performance efficiency in the Jordanian company for investment and supply-Safeway: An empirical study. Invention Journal of Research Technology in Engineering \& Management, 2(2), 14-23.

Al-Hayek, S., \& Masaad, Z. (2008). Challenge that faces the students of basic phase when they doing the activity in sport classes the first international scientific conference of the faculty of physical education and sports science at the Hashemite university. Jordan

Al-Jawarneh, N. M. S. (2016). Case study: Business management school at the Turkish republic of north Cyprus and how strategic thinking and planning can improve the performance of the organization to maintain stable between competitors. Invention Journal of Research Technology in Engineering \& Management (IJRTEM), 1(5), 64-72.

Aljawarneh, N. M. S., \& Atan, T. (2018). Linking tolerance to workplace incivility, service innovative, knowledge hiding, and job search behavior: The mediating role of employee cynicism. Negotiation and Conflict Management Research, 11(4), 298-320.

Aljawarneh, N., \& Al-Omari, Z. (2018). The role of enterprise resource planning systems ERP in improving customer relationship management CRM: An empirical study of Safeway company of Jordan. International Journal of Business and Management, 13(8), 86-100.

Al-Omari, Z. S., Aljawarneh, N., Davut, S., \& Salah, A. (2018). The impact of marketing mix elements on forming mental images about Islamic banks in Jordan: An Empirical Study. OFFICIAL, 12, 54.

Al-Omari, Z., Alomari, K., \& Aljawarneh, N. (2020). The role of empowerment in improving internal process, customer satisfaction, learning and growth. Management Science Letters, 10(4), 841-848.

Alshare, F., Aljawarneh, N., Alomari, K., Alomari, Z., Albdareen, R., AAlwagfi, A., \& Alradaideh, A. (2020). Factors influencing cellular device purchase decisions in Jordan. Management Science Letters, 10(11), 2501-2506.

Alwagfi, A. A., Aljawarneh, N. M., \& Alomari, K. A (2020). Work ethics and social responsibility: Actual and Aspiration. Journal of Management Research, 12(1), 26-36.

Audley, P. (2002). People with physical and sensory disabilities, participation levels and barriers to physical activity. The Department of Public Health, Western Health Board.

Cam, L., Xuan, Q., Anh, T., \& Phuong, T. (2019). Exploring factors influencing on students' intention on institutional persistence. Management Science Letters, 9(13), 2229-2240.

Council of Europe. Directorate of Legal Affairs. (1986). Judicial Power and Public Liability for Judicial Acts: Proceedings of the Fifteenth Colloquy on European Law, Bordeaux, 17-19 June 1985 (Vol. 15). Manhattan Publishing Company.

Davis, A. M., Webborn, P. J., \& Salt, D. W. (2000). Robust assessment of statistical significance in the use of unbound/intrinsic pharmacokinetic parameters in quantitative structure-pharmacokinetic relationships with lipophilicity. Drug Metabolism and Disposition, 28(2), 103-106.

Dalila, D., Latif, H., Jaafar, N., Aziz, I., \& Afthanorhan, A. (2020). The mediating effect of personal values on the relationships between attitudes, subjective norms, perceived behavioral control and intention to use. Management Science Letters, 10(1), 153-162.

Goodman, E., \& Whitaker, R. C. (2002). A prospective study of the role of depression in the development and persistence of adolescent obesity. Pediatrics, 110(3), 497-504.

Hassan, S., \& Din, B. (2019). The mediating effect of knowledge sharing among intrinsic motivation, high-performance work system and authentic leadership on university faculty members' creativity. Management Science Letters, 9(6), 887-898.

Khoja, A., \& Omar, M. (2008). Obstacles to practicing sports activity within the centers of special needs in Algeria. The first international scientific conference of the faculty of physical education and sport science at the Hashemite university.

Khuong, M., Nguyen, N., \& Nguyen, T. (2020). Elements influence international tourists' satisfaction. Management Science Letters, 10(11), 2463-2476.

Mahafzah, A. G., Aljawarneh, N. M., Alomari, K. A. K., Altahat, S., \& Alomari, Z. S. Impact of customer relationship management on food and beverage service quality: The mediating role of employees satisfaction. Humanities \& Social Sciences Reviews, 8(2), 222-230.

United States. Department of Education. Planning, Evaluation Service, \& Abt Associates. (1997). Prospects: Final report on student outcomes (Vol. 2). Abt Associates Incorporated.

Yaiya, S. (2005). Obstacles to sports activities for people with special needs in Yemen. Unpublished. Master Thesis Yarmouk University. 
(C) 2020 by the authors; licensee Growing Science, Canada. This is an open access article distributed under the terms and conditions of the Creative Commons Attribution (CC-BY) license (http://creativecommons.org/licenses/by/4.0/). 